
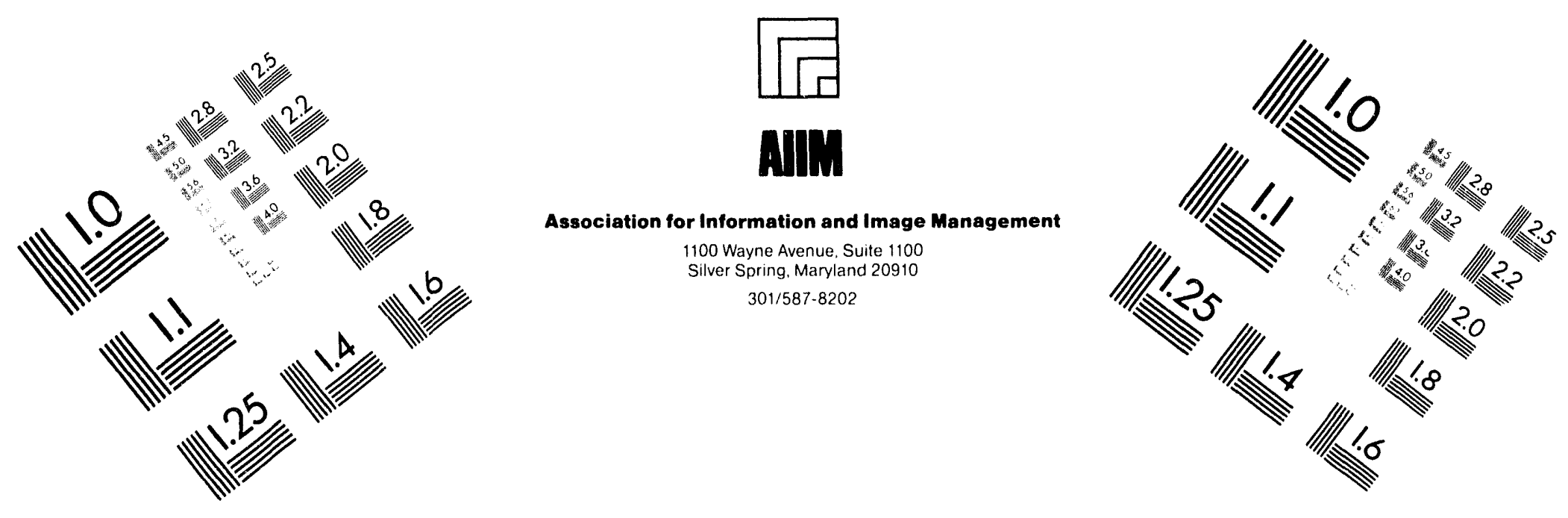

\title{
Centimeter
}

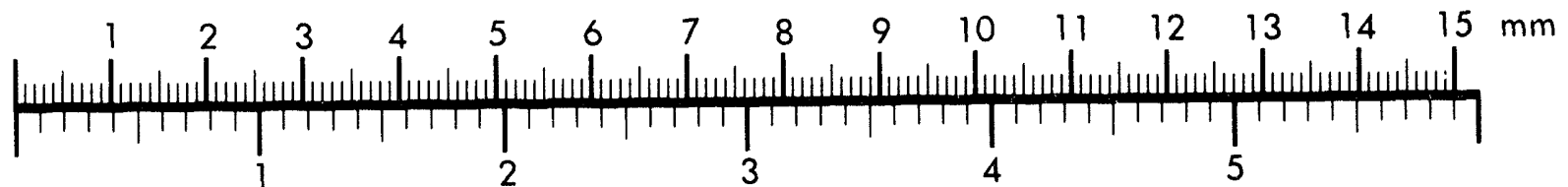

Inches
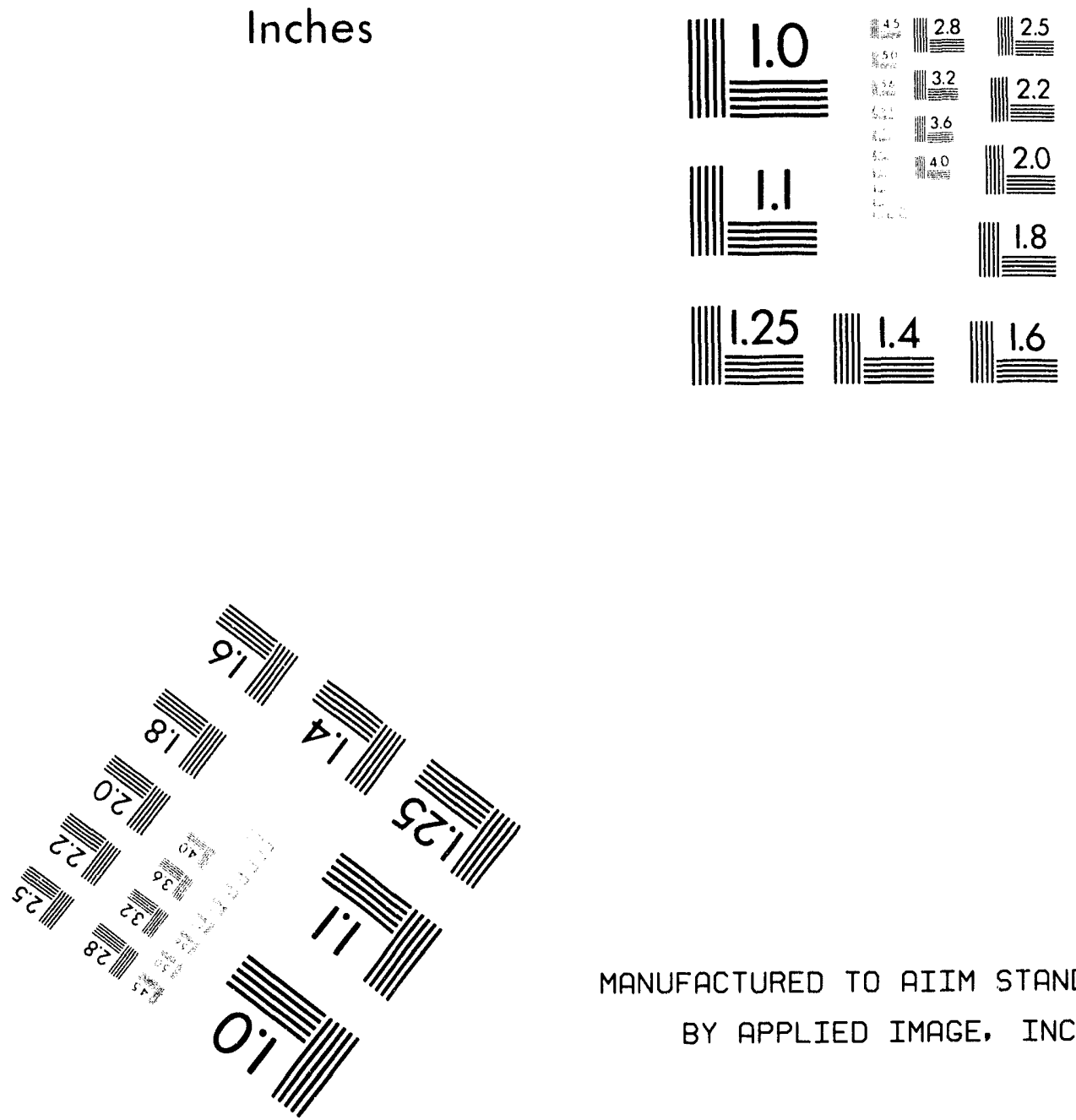

MANUFACTURED TO AIIM STANDARDS

BY APPLIED IMAGE. INC.

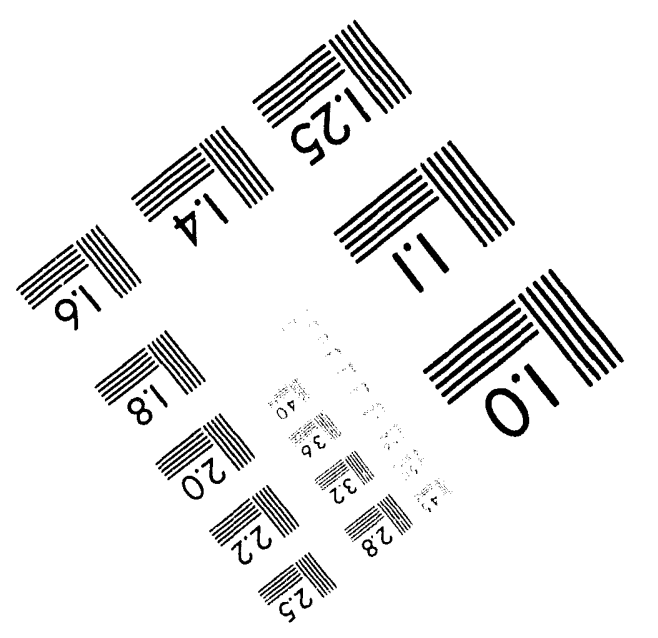



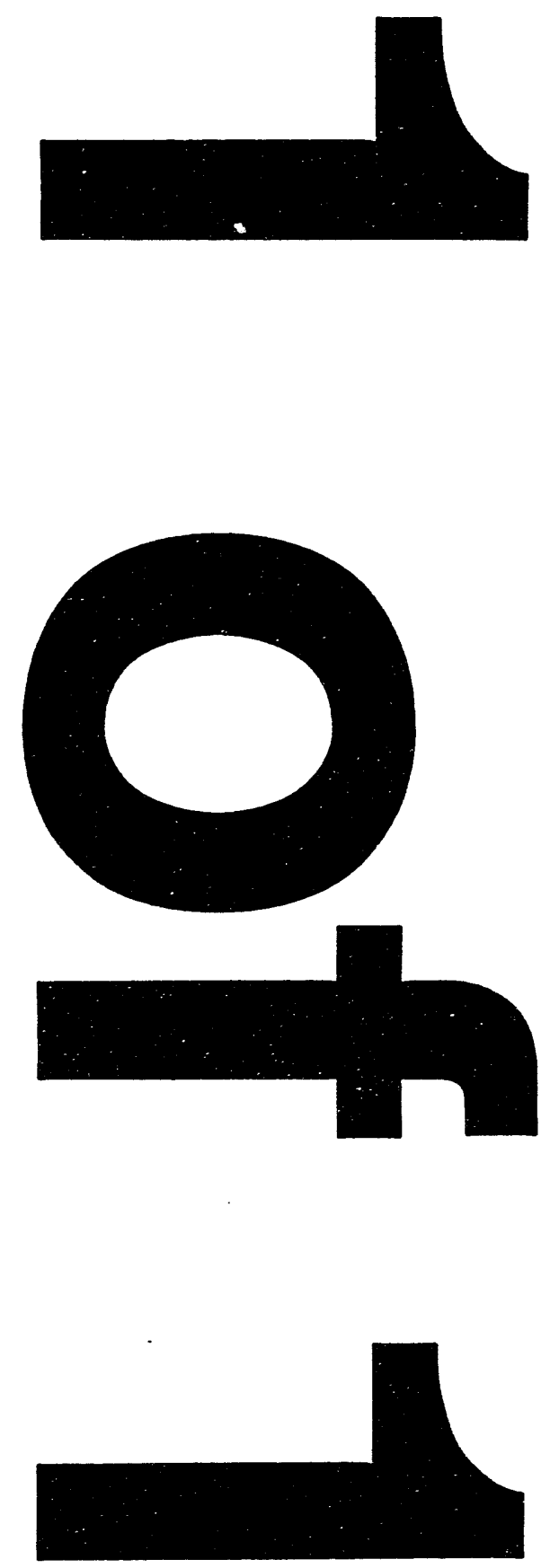


\section{HW 777528}

Cover Sheet for a Hanford

Historical Document

Released for Public Availability

Released 1994

Prepared for the U.S. Department of Energy

under Contract DE-AC06-76RLO 1830

Pacific Northwest Laboratory

Operated for the U.S. Department of Energy

by Battelle Memorial Institute

\%attelle 


\section{DISCLAIMER}

This is a historical document that is being released for public availability. This was made from the best available copy. Neither the United States Government nor any agency thereof, nor Battelle Memorial Institute, nor any of their employees, makes any warranty, express of implied, or assumes any legal liability or responsibility for the accuracy, completeness, or usefulness of any information, apparatus, product, or process disclosed, or represents that its use would not infringe privately owned rights. The views and opinions of authors expressed herein do not necessarily state or reflect those of the United States Government or any agency thereof. 


\section{GENERAL ELECTRIC}

HANFORD ATOMIC PRODUCTS OPERATION - RICHLAND, WABHINGTON

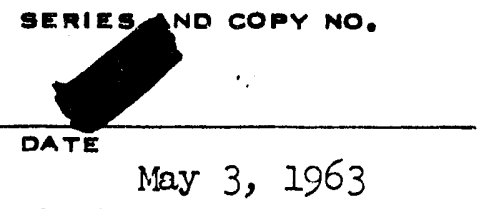

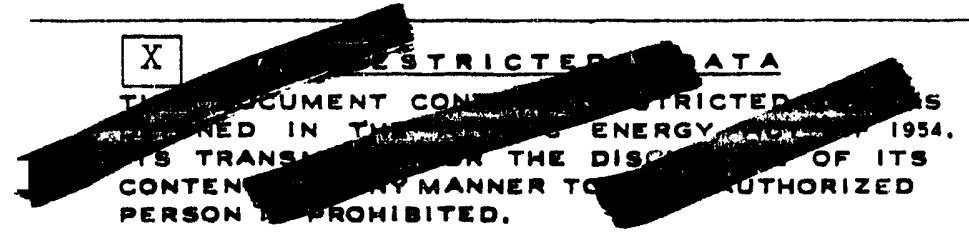

OTHER OFFICIAL CLABBIFIED INFORMATION

THIS MATERIAL CONTAINB INFORMATION AFFECTING THE NATIONAL DEFENSE OF THE UNITED STATES WITHIN THE MEANING OF THE ESPIONAGE LAWS, TITLE 18, U.S.C., SECS. 793 AND 794, THE TRANSMISSION OR REVELATION OF WHICH IN ANY MANNER TO AN UNAUTHORIZED PERBON IS PROHIEITED BY LAW.

TITLE

CRUD DEPOSITION IN KER LOOPS AT PH $10 \mathrm{IiOH}$

\section{AUTHOR}

D. R. Dickinson

T. F. Dermitt
SEREDERTIVG COPY RECEIVES 200 D AREA

yal if is:?

RE: LKM TO

ISCHNICAL :NFORIAATION FIL:

THIS DOCUMENT TT NOT BE LEFT YM ENDED OR WHERE MUNAUTHORIZED PERSON MAPHAVE ACCESS

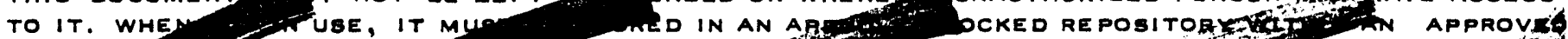

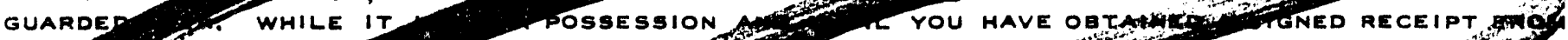

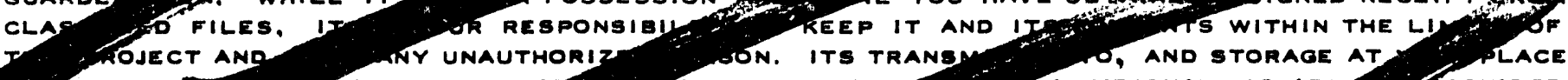
TRESIDEN UA THIEITED. IT THE RELATED TO BE DUPLIG WON. ITS TRANBM NO, AND STORAGE AT CLACE TO SIGN IN THE BPACE PROVIDED BELOW. ROUTE TO: MLEDING THIS DOCUMENT MLL REQUE PAYROLL NO.

LOCATION
TILADING THIS DOCUMENT

signatuRE AND DATE

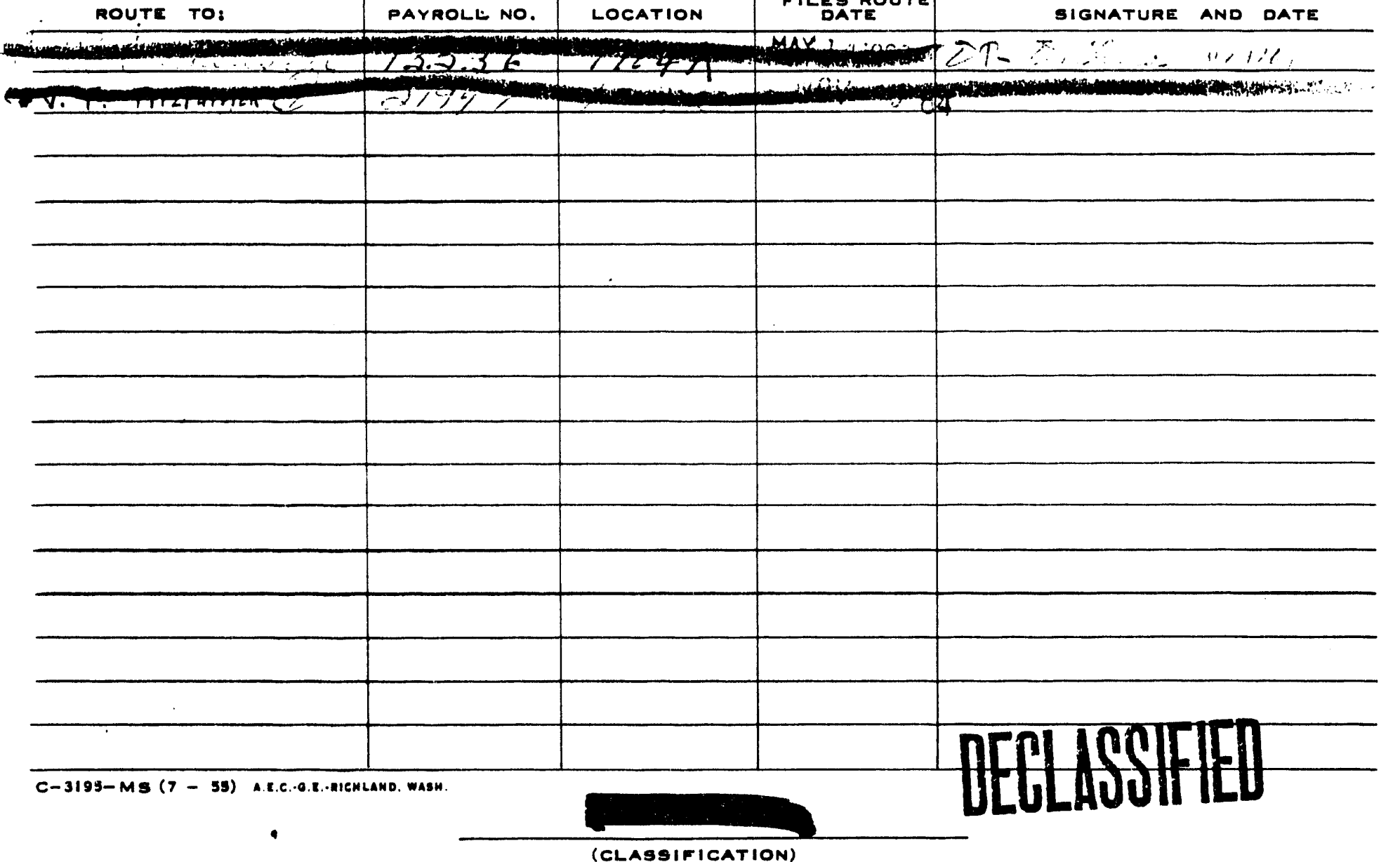




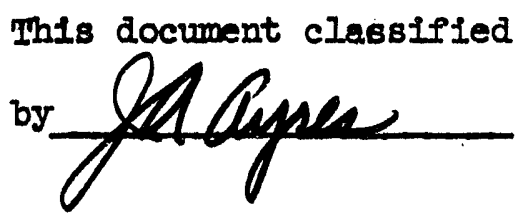

This document consists of pages, No. of

May 3, 1963

CRUD DEPOSITION IN KER LOOPS AT PH 10 LIOH

D. R. Dickinson and T. F. Demitt

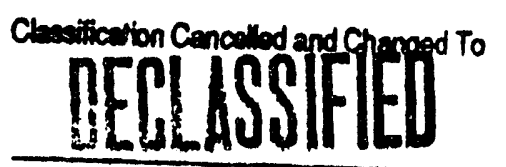

By Authorty of $R M$ leteu

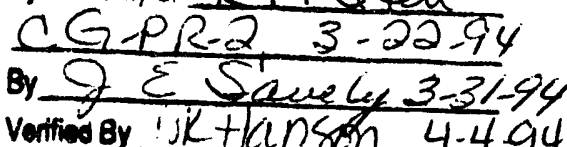

12 copies.

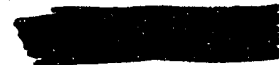

\section{DISCLAIMER}

This report was prepared as an account of work sponsored by an agency of the United States Government. Neither the United States Government nor any agency thereof, nor any of their employees, makes any warranty, express or implied, or assumes any legal liability or responsibility for the accuracy, completeness, or usefulness of any information, apparatus, product, or process disclosed, or represents that its use would not infringe privately owned rights. Reference herein to any specific commercial product, process, or service by trade name, trademark, manufacturer, or otherwise does not necessarily constitute or imply its endorsement, recommendation, or favoring by the United States Government or any agency thereof. The views and opinions of authors expressed herein do not necessarily state or reflect those of the United States Government or any agency thereof.

DISTRIBUTION OF THIS DOCUMENT IS UNLIMITED

\section{HANFORd ATOMIC PRODUCTS OpERATION RICHLAND. WASHINGTON}

\section{NOTICE!}

This report was prepared for use within General Electric Company in the course of work under Atomic Energy Commission Contract AT-(45-1)-1350, and any views or opinions expressed in the report are those of the authors only. This report is subject to revision upon collection of additional data.

\section{LEGAL NOTICE}

This report was prepared as an account of Government sponsored work. Neither the United States, nor the Commission, nor any person acting on behalf of the Commission:

A. Makes any warranty or representation, express or implied, with respect to the accuracy, completeness, or usefulness of the information contained in this report, or that the use of any information, apparatus, method, or process disclosed in this report may not infringe privately owned rights; or

B. Assumes any liabilities with respect to the use of, or for damages resulting from the use of any information, apparatus, method, or process disclosed in this report.

As used in the above, "person acting on behalf of the Commission" includes any employee or contractor of the Commission to the extent that such employee or contractor prepares, handles or distributes, or provides access to, any information pursuant to his employment or contract with the Commission.
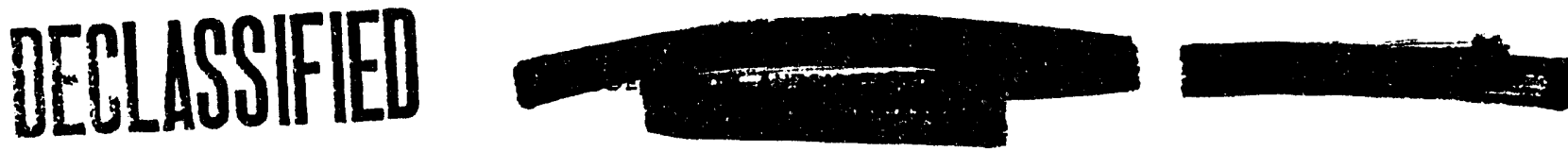
1. F. W. Albaugh

2. J. A. Ayres

3. T. F. Demitt/V. F. FitzPatrick

I1. T. F. Demitt/

5. H. Harty

6. W. K. Kratzer/B. S. Kosut

7. C. G. Iewis/L. V. Barker

8. M. C. Ieverett

9. J. W. RIches

10. R. E. Trumble

11. 300 File

12. Record Center 
One of the problems which may be encountered in the operation of NPR, or of any similar pressurized-water reactor, is the deposition of crud in the reactor core, particularly on the surfaces of the fuel elements. This crud consists primarliy of iron oxldes resulting from the corrosion of the piping. It has generally been found to deposit preferentially in a radiation fleld such as is present in the reactor core. Such deposition is undesirable for two reasons. First, the crud will become activated, and on subsequent release may create radioactivity levels in the ex-reactor components of the primary loop high enough to be a hazard to nalntenance and operating personnel. Secondly, the crud deposit is a poor conductor of heat, and even a rather thin film can raise the cladding temperature by $100-200^{\circ} \mathrm{C}$ and result in accelerated corrosion of the cladding.

\section{SUMMARY}

Two instances of major crud deposition have recently been encountered in the in-reactor KER loops during operation at $\mathrm{pH} 10 \mathrm{IHOH}$.

The test in KER-1 (carbon steel) lasted 2 weeks and followed a cleaning of the loop with amonium citrate. Crud concentration in the water was abnormally high; the last part of the test was at low temperature which resulted in even higher crud concentration. A falrly heavy dark-brown crud deposit was found both on Zircaloy-clad fuel elements and on the unautoclaved zircaloy sleeves surrounding them.

The test in KER-2 (stainless steel) lasted 4 months and followed installation of new heat exchangers. Water quality during the test was good, except for one Instance when cleaning solution was inadvertently introduced during the cleaning of KER-1. A deposit similar to that in KER-1 was found on the sleeves, but very little on the fuel elements.

These two instances are the first of any significant crud deposition in the KFR loops during high $\mathrm{pH}$ operation.

\section{Previous KKRR Experience}

Prior to the two tests described below, crud deposition has not been encountered during high pH operation of the KER loops. Loop 1 (carbon steel) has operated at $\mathrm{pH} 10$ IHOH since its initial start-up in February, 1958. Loops 2, 3, and 4 (stainless steel) have operated at pH 10 IHOH since November, 1958, October 1959, and February 1960 respectively. Outlet temperatures during these periods ranged from 200 to $288 \mathrm{C}$. During and between these tests, process water was on several occasions introduced into the in-reactor portion of the loops. During this time no significant amount of crud has been observed on discharged fuel elements or spacers, or caused any serious problem of radioactivity release as crud bursts. The characteristic shiny black autoclave film was commonly visible on the discharged elements. In a couple of instances, the 
elements were coated with a thin dull soot-like film, thinner and considerably different in appearance than the iron-oxide deposit described in the following section.

The stainless steel loops had formerly operated at neutral and reduced $\mathrm{pH}$. At $\mathrm{pH}$ 6, the fuel elements and spacers (Zircaloy, stainless steel and aluminum) were covered with a moderately heavy red-brown mist-like film. At pH 4.5 with phosphoric acid, heavy deposition of a similar film occurred on Zircaloy and aluminum fuel cladding and on stainless-steel and aluminum spacers.

Test K-1-16

This test immediately followed a period of non-standard loop conditions. The KER-1 loop had been modified by the installation of new larger heat exchangers and pumps and other minor changes. Following this modification several tests without fuel elements were conducted in the loop in the period November 12 , 1962 to February 16, 1963. These tests involved intentional rusting of the loop piping, tests of procedures for cleaning the piping, and the use of ammonium hydroxide for $\mathrm{pH}$ control. On January 29 the ex-reactor portion of the loop was cleaned with ammonium citrate, which removed the rust and film from the piping surfaces, and established a fresh surface for subsequent operation. This cleaning was followed by 4 days clean-up with $\mathrm{NH}_{4} \mathrm{OH}, 8$ days at $\mathrm{pH} 10 \mathrm{IiOH}$ at $180-200 \mathrm{c}$, during which time the crud concentration in the water were normal. After this the loop was down 5 days for maintenance.

The 10op was charged on February 16, 1963, with twelve 17.3-inch NIE-I fuel elements contained in Zircaloy sleeves. This test ran for 5 days at high temperature (outlet temperature of $250 \mathrm{C}$ maximum, $230 \mathrm{C}$ average), followed by 9 days at low temperature ( $90 \mathrm{C}$ outlet) due to a leak in the front nozzle. The fuel was discharged on March 4. During the test the water was kept at pH 10 with LHOH, except for a short period during the first day of the test when some acidic cleaning solution trapped in the lines was valved in causing the $\mathrm{pH}$ to drop to 7.2 . The crud concentration in the water was abnormally high during the test, particularly during the latter period at reduced temperature. Further details of the water quality before and during this test are given in HW-77356.(1)

The day after discharge, the fuel elements were removed from their sleeves and examined through the telescope at the 10-foot level of the $K E$ examination basin. All were covered with a dark-brown crud film of moderate intensity. The amount of crud was probably small, but was sufficlent to cover the surface, except on a portion of the surface of one element where the black autoclave film could be seen. The sleeves, which had not been autoclaved, had about the same crud deposit as the fuel elements. The stainless steel spacers had a simflar deposit, but a bit lighter and less uniform. There was little difference between stainless steel exposed in-flux and out-of-flux.

(1) Larrick, A.P., T.F. Demitt, and V.F. FitzPatrick, Chemical Cleaning and Operation of the KRR-I Test Facility, 11/12/62 through 3/5/63, HW-77356, March 31, 1963. Unclassified. 
Photographs of the crud deposit on the upstream, center, and downstream fuel elements in the charge are shown in Figures 1, 2, and 3, respectively. The slight differences in appearance between these three elements are probably due primarily to slight differences in lighting since visual observation Indicated little difference in crud deposit with position. The shiny metalic spots in these photographs are due to scraping the film in handing after discharge. Figure 4 shows a typical zircaloy sleeve. The red-brown deposit seen on the carbon-steel supports resulted from contact with process water in the storage basin and was not present when discharged.

The operation at low temperature during the latter part of the test resulted in high concentration of radiolytic oxygen and hydrogen peroxide in the coolant, since at low temperature the recombination of the products of radiolysis is slow. It is belleved that the adherent magnetite $\left(\mathrm{Fe}_{3} \mathrm{O}_{4}\right)$ f1Im on the piping was oxidized under these conditions to non-adherent ferric oxide $\left(\mathrm{Fe}_{2} \mathrm{O}_{3}\right)$, and that this was the cause of the greater concentration of crud encountered during this period at low-temperature. It is therefore likely that the amount of material deposited on the elements would have been mach smaller if this low-temperature operation had not been encountered. However, this should not be considered as the sole cause of the crud deposition, since on at least two previous occasions this loop has operated at low temperature at $\mathrm{pH} 10 \mathrm{LHOH}$ at the end of a fuel exposure without any crud deposition. It seems likely that the magnetite film on the piping was never fully restored to its normal equilibrium condition following the last cleaning, and that the rate of release of corrosion products from the plping surfaces were therefore abnormally high during the test. The contamination with acidic cleaning solution undoubtedly also aggrevated this condition.

Test $\mathrm{K}-2-15$

Eight 17.3-inch Zircaloy-clad NIE-I fuel elements in unautoclaved Zircaloy sleeves were charged in KERR-2 (a stainless steel loop) on November 27, 1962, and discharged March 25, 1963. These fuel elements and sleeves were the same as those irradiated in Test $\mathrm{K}-1-16$. Prior to the start of this test KFR-2 had been down since March 29, 1962, for a modification similar to that conducted on KER-1. During the test, the water was maintained at $\mathrm{pH} 10$ with IfOH. The water quality was good with the one exception noted below. The outlet temperature was 210-235 C for 54 days during the early part of the test, and 175-185 C for 31 days during the latter part of the test; the loop also had 34 days of low-temperature operation when the reactor was down and during shut-down and start-up.

On Jamary 29, 1963, during reactor operation with the loop at high temperature, some ammonium citrate cleaning solution was inadvertently added to the recirculating coolant with the feedwater stream during feed-and-bleed operation. Within a few hours the $\mathrm{pH}$ decreased from 10 to 6.5 , the specific resistance decreased to $1.3 \times 10^{3} \mathrm{ohm}$-centimeters, the total solids concentration increased from about $8 \mathrm{ppm}$ to about $225 \mathrm{ppm}$, and a serious crud burst occurred that increased the coolant activity level considerably. Magnetite particles were observed in the coolant confirming the crud burst. The loop water quality prior to this incident had been normal. 
Corrective action taken as soon as the chemical contamination was discovered Included: (1) flushing and refiling the storage tank with delonized water to remove the cleaning solution, (2) adding lithium hydroxide to the recirculating coolant to raise the $\mathrm{pH}$, and (3) Increasing the feed-and-bleed purification rate to facilitate rapid dilution of the recirculating coolant stream. These actions were extremely effective as evidenced by the fact that the coolant had returned to near normal conditions within about 24 hours. At this time the pH was 10, the total solids concentration was $15 \mathrm{ppm}$, the specific resistance was $4 \times 10^{4}$ ohm-centimeters, the coolant activity was near normal, and there was no further evidence of magnetite particles in the coolant samples. The water quality conditions continued to improve during subsequent operation; thus there was no apparent permanent damage to the system as a result of this Incldent. A more detalled discussion of the loop, water quality prior to, during, and after this incident is described in $\mathrm{H} N-77388$. (2)

The charge was visually examined the day after discharge using the telescope at the 10-foot level of the $\mathrm{KE}$ examination facility. The unautoclaved Zircaloy-2 sleeves were covered with a falrly heavy unfform dark-brown crud deposit much like that found on the fuel elements and sleeves from $K=1-16$. No effect of turbulence on the intensity of deposition was noticed at the ends, near the supports, or where the OD was cut down. There was no indication of flaking off of the deposit. The fuel elements, by contrast, had either no crud, or only a very light thin crud film below which the shiny black autoclave film could still be seen.

The crud deposition in this test is harder to explain than that in $\mathrm{K}-1-16$, since the test was generally characterized by good water quality. The modification of the loop prior to the test, particularly the installation of new heat exchangers, Introduced fresh steel surfaces which would have corroded and released corrosion product at an abnormally high initial rate for a few days until a stable magnetite film could be formed. The introduction of cleaning solution probably also contributed to an abnormal formation of crud. The relative absence of crud on the fuel elements compared to the sleeves is puzzling. Previous experience, both at Hanford and elsewhere, indicates that crud is more apt to deposit on fuel than on non fuel surfaces.

Since the charge operated for|about two months with good water following the introduction of cleaning solution, it is possible that a heavier deposit originally formed and that some of it was slowly removed during subsequent operation.

\section{Future Work}

The occurrence of crud deposition in these two tests points up the need for continued study to determine what conditions which may be encountered in NPR might lead to crud problems and what can be done to reduce or eliminate crud deposition in these cases. Crud concentration in the coolant and its deposition

(2) FitzPatrick, V.F., Dibasic Ammonium Citrate Contamination of the KER-2 and KRR-4 Loops. HW-77388, 5-3-63, Unclassified. 


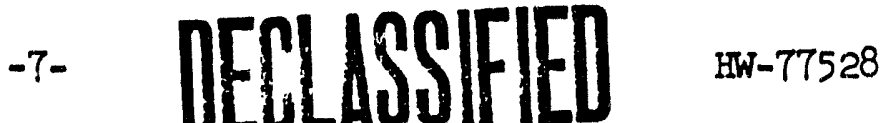

on the fuel charge will therefore contime to be monitored in all KER tests. In order to assess the serlousness of crud deposition such as was observed during these tests, a thermocouple slug is needed to measure the resulting increase in cladding temperature.

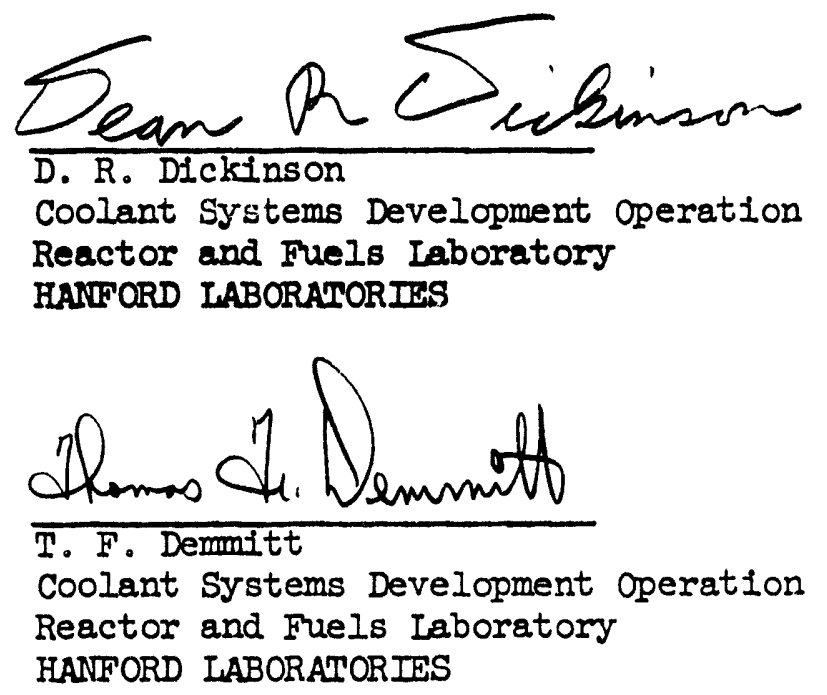

DRD:mf 


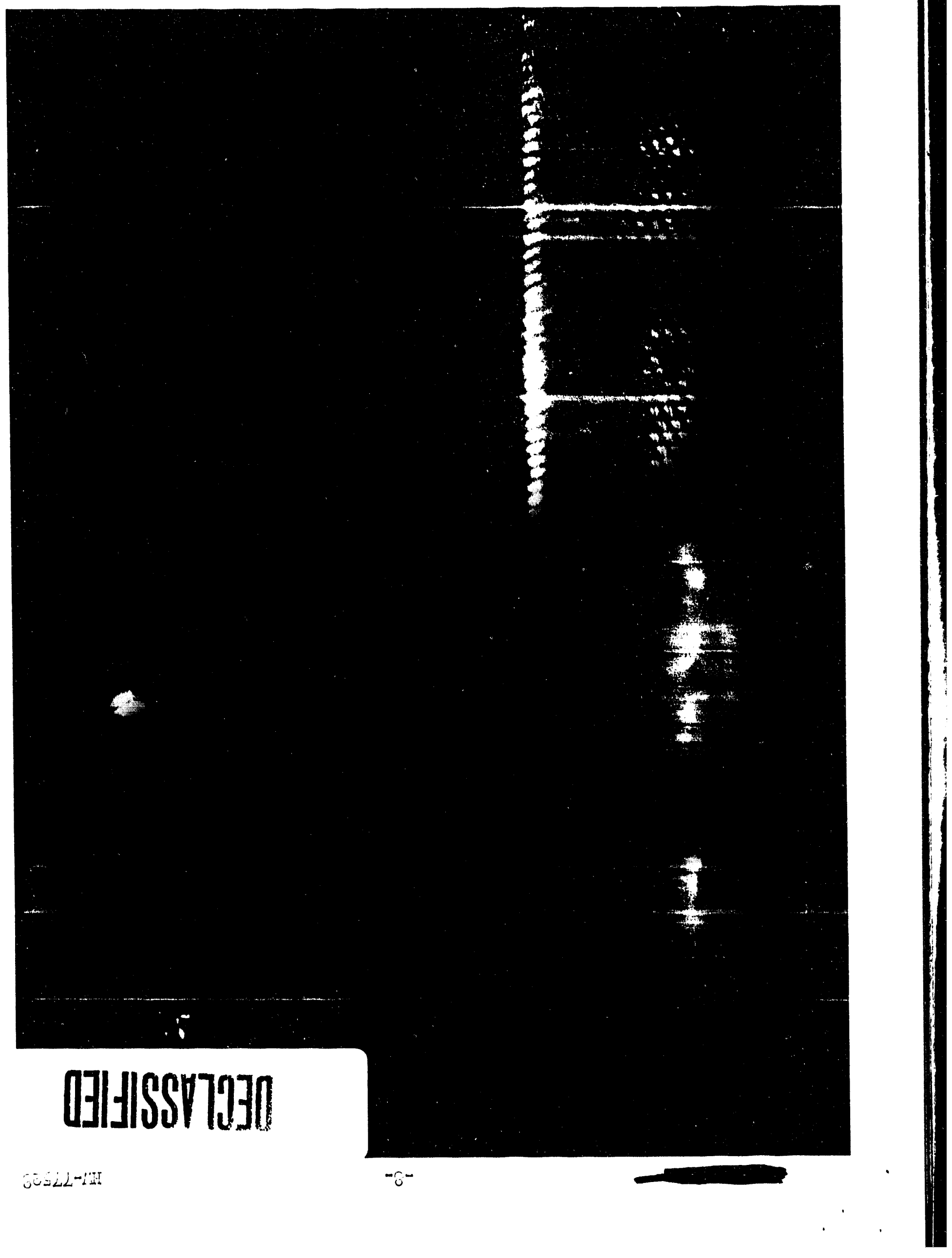




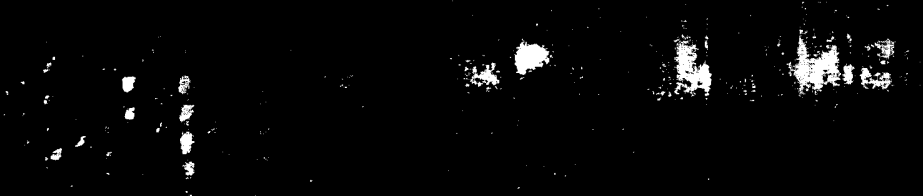

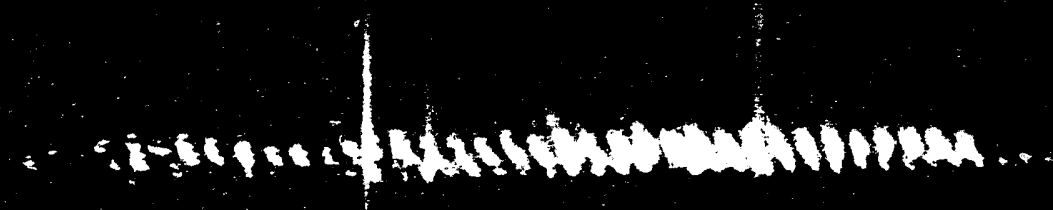




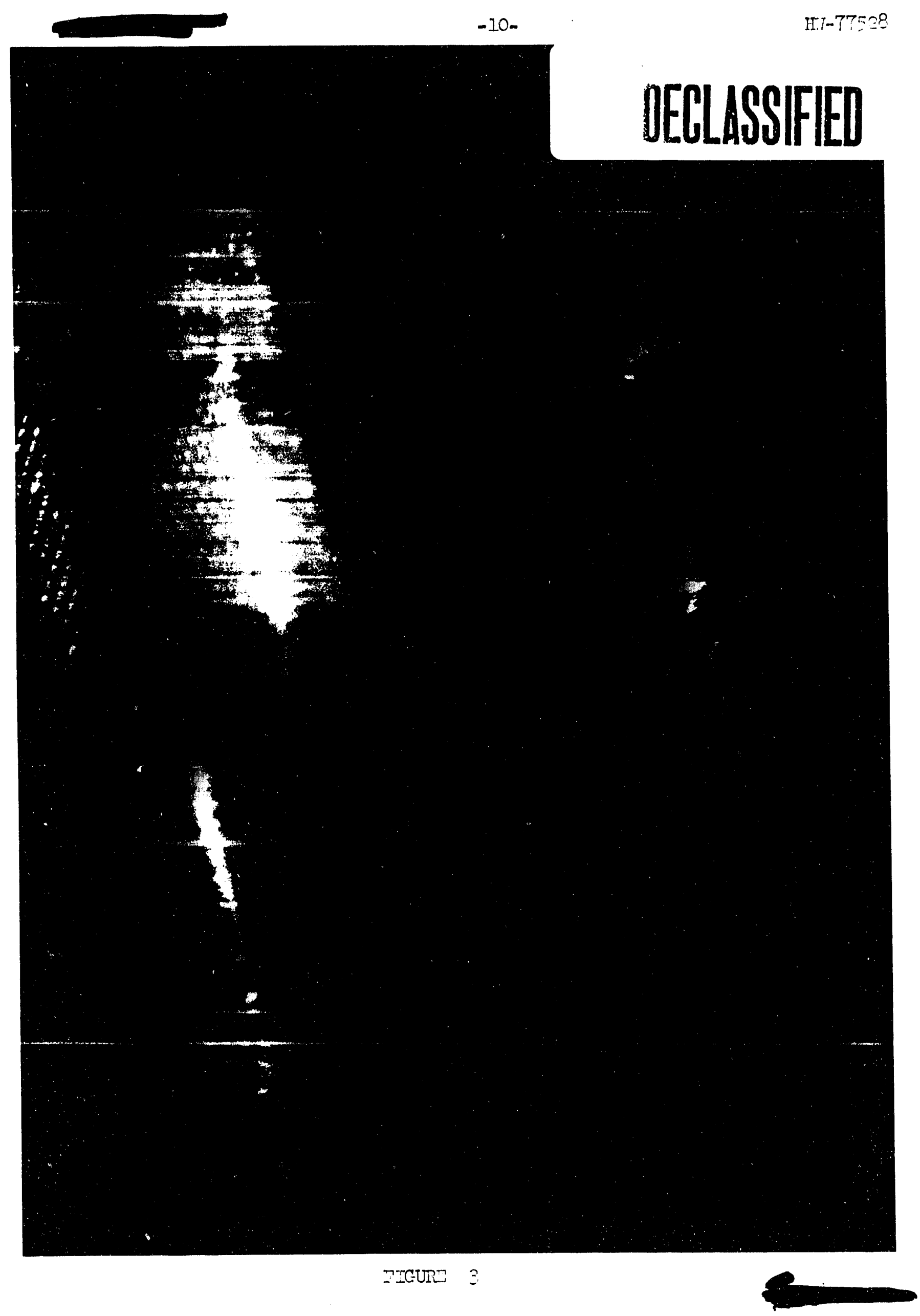



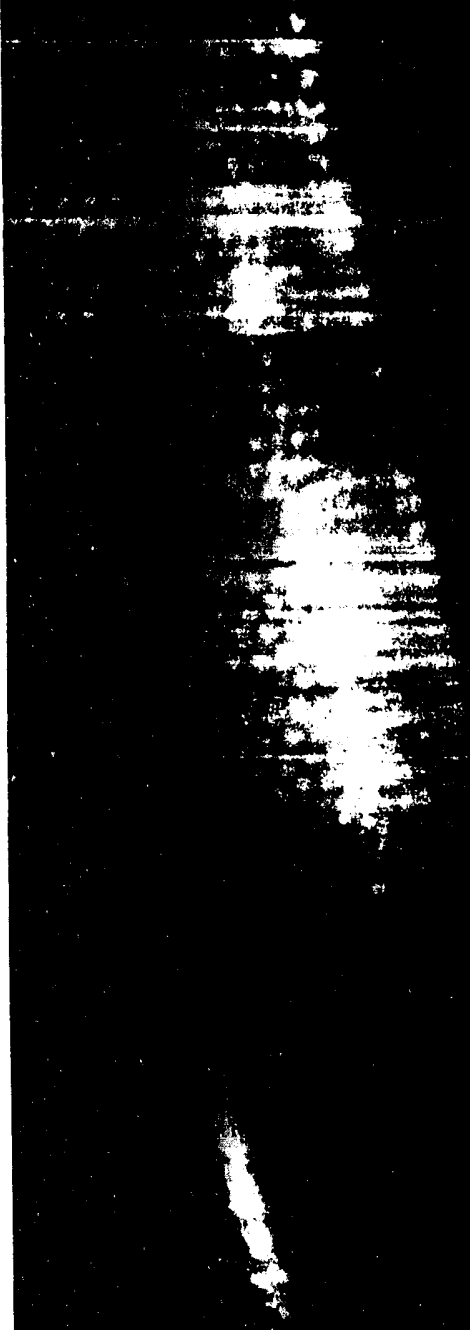

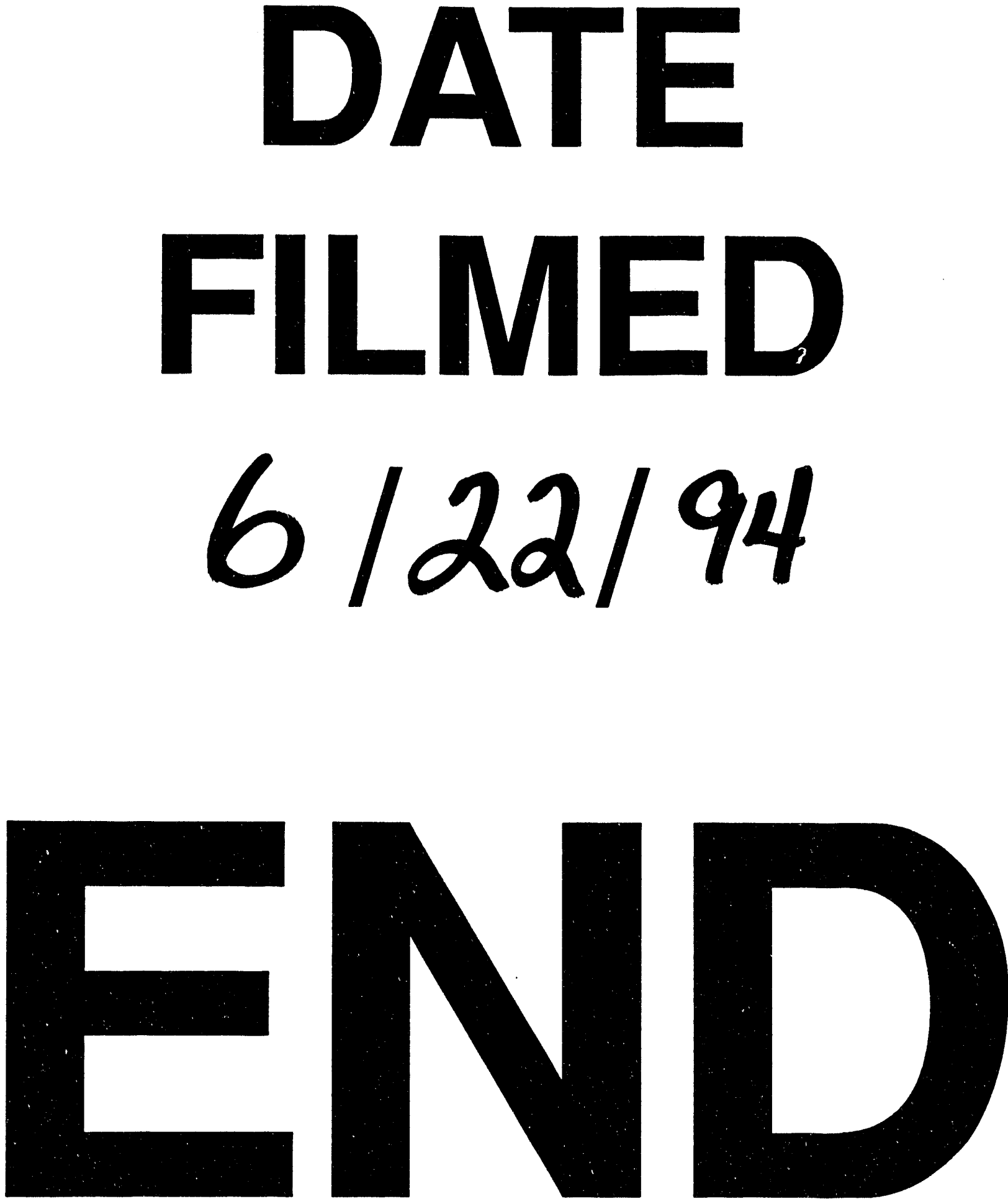
